\title{
Main Problems of Protection of Shareholder's Rights in Georgia
}

\author{
Khatuna Jinoria (PhD Candidate)
}

Grigol Robakidze University, Georgia

Doi: 10.19044/esj.2017.v13n31p64 URL:http://dx.doi.org/10.19044/esj.2017.v13n31p64

\begin{abstract}
The development of market and fair competition is based on the protection of individuals' rights including shareholders' rights. The interests of investors are ensured by solid legal guarantee. It is however important to keep in mind that the important goal of drawing the attention of investors should not jeopardize the rights of minority shareholders. Shareholders' rights drew the attention of scholars from the very beginning. Despite the efforts of numerous authors, development of case-law and several legal reforms, the way to solve the difficulty that arose due to contradiction between the interests of those two groups - minority and majority shareholders - is still missing. After "velvet revolution", in an attempt to create an attractive environment for foreign investors, Georgian legislators went overboard and broke the balance at minority shareholders stake. It is very important to finally find the right balance to protect both groups and also to ensure the normal functioning of the company. The article is focused on the identification of the main problems of the protection of shareholders' rights in Georgian legislation and court practice. It overviews the legal model of regulation and outlines the directions of the necessary legislative reforms. The deficiencies that violate minority shareholders' rights on legislation level by setting unclear and unbalanced procedures were sorted out. The article also offers general directions of legal amendments which are necessary to eliminate flaws in Georgian legislation and court practices.
\end{abstract}

Keywords: Shareholders' rights, Protection of Minority Shareholders

\section{Introduction}

The pre-requisite for the development of market and fair competition is the protection of individuals' rights including shareholders' rights. The interests of investors are ensured by solid legal guarantees. It is however important to keep in mind that the interest of drawing the attention of large investors should not jeopardize the rights of minority shareholders. 
Shareholders' rights drew attention of scholars from the very beginning. Despite the efforts of numerous authors, development of case-law and several legal reforms, the way to solve the difficulty that arose due to the contradiction between the interests of those two groups - minority and majority shareholders - is still missing (Poisson, 1994, 1-2). "Striking the right balance between the interests of minority/majority shareholders or, in other categories, interests of minority shareholders and facilitation of the efficient takeover market, is one of the most troublesome tasks for the legislature and the judiciary in dealing with the squeeze-out cases"( Miliutis, 2013, 770).

After "velvet revolution" in an attempt to create an attractive environment for foreign investors, Georgian legislators went overboard and broke the balance at minority shareholders stake. It is true that the decision of the constitutional court of Georgia that declared the first redaction of mandatory acquisition of shares anticonstitutional had a slight impact to slow down this process. It also aims to make legislative bodies to keep in mind minority shareholders' rights as well. Nevertheless, the results were not comforting.

The article is focused on the identification of the main problems of the protection of shareholders' rights in Georgian legislation and court practice, overviews the legal model of regulation, and outlines the directions of necessary legislative reforms. The deficiencies that violate minority shareholders' rights on legislation level by setting unclear and unbalanced procedures for the compensation of the restriction of their property rights were sorted out. Therefore, the article also offers general directions of legal amendments that are necessary to eliminate flaws mentioned above.

The research is based on general scientific methodology. Abstractivelogical methodology is broadly used which includes analysis and synthesis, induction and deduction. Comparative legal methodology of research was also applied.

The article consists of six main chapters, where all the important issues in the process of protection of shareholder's rights are discussed. In the conclusion, the results of the research are summarized and necessary recommendations for further development of the topic are provided.

\section{Shareholders' Rights and Obligations and their Classification}

It is declared that shareholder's sole obligation is to make transition. Consequently, the spectrum of shareholder's rights that is declared by all legal systems in one way or another includes the following:

- $\quad$ Right to dividends;

- $\quad$ Right to attend general meeting and vote;

- $\quad$ Right to demand early general meeting; 
- $\quad$ Access to information;

- $\quad$ Opportunity to Inspect Corporate Books and Records;

- $\quad$ The Right to Sue for Wrongful Acts.

Traditionally, shareholders' rights are divided into managerial and economic rights. Recently in Georgian legal doctrine, a new system of classification was offered as an analogy of Germany. According to this system, shareholders' rights are divided into individual and based on percentage rights; general meeting related rights and rights independent from general meeting; special rights and based on membership rights (Burduli Irakli, 2013, 40). The article offers new criteria of classification of shareholders' rights. It is considered appropriate to classify those rights into three main groups: Managerial rights, Property rights, and Protective rights. Managerial rights are subdivided into two subcategories: general meeting related rights and rights independent from general meeting. It seems slightly unclear of the reasons to indicate 'based on membership rights' as a separate group. Furthermore, all shareholder rights and obligations are based on holding shares in a company and do not exist separately, although some rights follow their owner even after the transfer of ownership of shares (right to receive dividends, non-concurrency rules, obligation to keep confidentiality). Nevertheless, they still originated from the fact of being a partner in a company. In addition, being based on membership is a characteristic of all shareholders' rights and not a separate group.

Before discussing each group of rights closely, it is appropriate to analyze the legal nature of stocks. The stock in its pure legal nature is a nonmaterial property - right of demand. The rights and obligations that emerge from the ownership of shares have their legal scope. The most important amongst them is the right to dividends. The other managerial or protective rights stand to ensure and empower partner's right to dividends.

Except for entitlement to dividends, the stocks are primarily connected to voting rights. Generally, different classes of stocks establish different rights. The aim of emission of differently classed shares is to control who holds voting rights. Georgian legislation directly acknowledges only two main classes of shares: common and preferred. The international market is familiar with three more classes of stocks that neither Georgian legislation nor practice has accepted yet. The classification of stocks is a good way to control shareholders' rights within the company, to limit voting rights of target groups and, if necessary, to ensure investors have their entitlement to dividends without transferring managerial powers. Preferred stock represents some degree of ownership in a company, but usually does not come with the same voting rights. With preferred shares, investors are usually guaranteed a fixed dividend. Recall that this is different from that of common stock, which has variable dividend payments that fluctuate with 
company profits. Unlike common stock, preferred stock doesn't usually enjoy the same appreciation (or depreciation in market downturns) in stock price, which results in lower overall returns. One advantage of preferred stock is that in the event of bankruptcy, preferred shareholders are paid off before the common shareholder. Sadly, this mechanism of solving problem is completely ignored by Joint Stock Companies (JSC) in Georgia.

\section{Managerial Rights}

The group of managerial rights include the following rights that are connected with the management of the company, decision-making, and controlling managerial bodies: the right to attend general meeting, voting rights, the right to demand early general meeting, the right to obtain information, preemptive right of acquisition of stocks, and opportunity to inspect corporate books and records.

The right to demand early general meeting, preemptive right to acquire stocks, and the right to inspect corporate books and records are dependent on the percentage of shares. Georgian legislation does not contain any specific or problematic rule concerning those rights.

Without providing shareholders' with information, their participation in general meeting will not be efficient. Shareholder ought to be regularly updated with information concerning important tendencies taking place in the company (Tsertsvadze Lasha, 2016, 78). The access to information on one hand is an important tool to protect minority shareholders, while on the other hand, the access to information contains several risks like the abuse of one's rights. In some cases, a shareholder owns stocks in other company which might even be concurring with the first company. In this situation, providing a shareholder with confidential details of upcoming bargain or the transaction in force might be risky and result to the leaking of information. Shareholder is entitled to address a court in case of the refusal in sharing the information. The court must be very careful while delivering justice and expel the risk of abuse of rights before putting obligation to share requested information on directors of the company.

It is quite unusual for Georgian shareholders to suits on directors' refusal based on access to information. Preserving 'happy medium' by the court in that kind of cases is crucially important to protect minority shareholders efficiently and to prevent the abuse of rights. For the sake of efficiency, it is important that time required to deal with this kind of suits was diminished to minimum, since it is vital to receive information on time and not to give a dominant shareholder an opportunity to destroy important evidences. For this purpose, if required, the decision of first instance court must be enforced immediately. On the other hand, court must rule out all the possibilities of wrongful usage of information and leaking confidential data 
against corporate interests. Of course, as in every civil case, the burden of proof lays on parties.

While speaking of shareholders' managerial rights, the proposition of French's corporate researcher, Marie-Danielle Poisson, must be considered. Prof. Poisson offers to engage minority shareholders into controlling bodies of the company (Poisson, 1994, 654). As Georgia recognizes two-tiered board system with board of directors and supervisory board separately, it should be in the very best interests of fair balance to appoint minority shareholder or a representative of such a group in supervisory board of JSC. The obligation to elect minority shareholders into the board must be declared by legislation and should not depend on the decision of corporate managers.

\section{Property Rights}

The main property rights of shareholders are preemptive right of acquisition of stocks and entitlement to dividends.

As mentioned above, preemptive right of acquisition of stocks is a percentage-related right. According to article 53 of Entrepreneurs Law of Georgia (EL), in case of the emission of new stocks by the company, all the shareholders have preemptive right of acquisition. However, the board is obliged to inform in person only shareholders who own at least $1 \%$ of voting stocks of the company. For the rest of the shareholders, making a public announcement is sufficient.

The right of dividends depends on both the percentage and classification of shares, as mentioned above. Concerning the entitlement to dividends, The Supreme Court of Georgia established common practice few years ago. According to clarifications of the Supreme Court, the share in the capital, owned by the partner of the company, is the right to demand economical and legal benefits, of which the right of dividends is the most important. The Court of Cassation distinguished the general right to receive dividends and the right to demand allotted portion of income at the end of an economic year - the right to demand dividends. The difference between them is that the general right of dividends originates as soon as a person acquires stocks of the company i.e. becomes the partner or shareholder. On the other hand, the right to demand dividends is granted to a shareholder after general meeting in making a decision on the marshalling of income between shareholders. In other words, the entitlement to dividends is a right dependent on the decision of general meeting. General right of dividends is linked with stocks and cannot be transferred separately from shares to another person (Decision of the Supreme Court of Georgia, 2011). The right to demand dividends can be applied even after the transition of stocks by former shareholder if it is stated that the decision of general meeting to divide income as dividends was made at the end of the economic year and 
given the fact that shareholder did not receive his lot. This kind of misuse of power by majority of shareholders happened quite often in Georgia during the past 20 years. Several cases were discussed by Georgian courts where single shareholder or the group of majority shareholders had held general meeting without inviting minority shareholders. Also, they had made decisions to split income into dividends among themselves. Thus, majority of them were simply deceived that there was no income to share as dividends. As soon as those abused shareholders found out about the breach of their rights and brought actions against companies and majority, the court granted them their portion of dividends.

The situation is completely different in cases where general meeting has not made the decision on marshalling income. The common practice is established that courts are not empowered to force corporate management to distribute dividends. No matter how unreasonable the decision of nondistribution of dividends is, only corporate bodies are entitled to make this kind of decision. However, it could be quite harmful to force JSC to use the income for dividends. It is presumed that managerial bodies of the company act in the best interest of JSC. Making the decision on how to marshal income is a great risk which is not justified even by the purpose of protection of minority shareholders. Of course, in case of abuse of power, the minority shareholders are granted the right to demand fair compensation from dominant partner directly.

\section{Protective Rights}

Under protective rights, the article unites the mechanisms that minority and majority shareholders have against each other. These mechanisms are: right to demand compensation of damage, mandatory acquisition of shares, mandatory tender offer, and shareholders' lawsuit.

To ensure normal activity of the company, it is of vital importance to keep minority and majority shareholders interests balanced. The system of protection of shareholders' rights is based on the presumption that majority of shareholders have in mind the interest of the company. Since they make bold investments, they are more interested in further development of the company. The majority risks more than minority and the sole interest of the minority shareholders' is to get dividends. The presumption seems slightly outdated in modern world. First, to maximize income is in the best interests of the both groups. Further development of business, widening the space in the market at the end equals to more profit. At least, one of the European researches considers this presumption as obsolete (Thamm, 2013). The author indicates more involvement of the minority shareholders in the process of managing company in Germany. Hence, the situation has not improved that much in Georgia. 
As mentioned above, the reform of EL was carried out to ensure comfortable environment for foreign investors. During the process, several legal amendments were made. For example, first, the complete antitrust regulations were taken down. Simultaneously, new Labor Code of Georgia was passed. The Code authorized an employer to terminate contract with an employee at any time without prior notice or giving any reasons. The amendments of EL were made with the same attitude. Thus, mandatory tender offer and first redaction of mandatory acquisition of shares were introduced in 2007. The main purpose of the adoption of the so called 'squeeze-out' was to liberate potential investors or other majority shareholders from post-soviet burden of former employees of factories and mills transformed into minority shareholders. In several months, The Constitutional Court of Georgia declared the institution of mandatory acquisition of shares anticonstitutional and void, but meanwhile minority shareholders of several large companies were effectively 'squeezed-out'. In 2008, new redaction of mandatory acquisition of shares was adopted. It supposedly was based on the decision of the Constitutional Court of Georgia, but not all of the recommendations of the court were taken into account. The institution of mandatory tender offer was not amended since 2007.

The approach is different with mandatory tender offer and mandatory acquisition of shares. Mandatory tender offer still leaves the chance to minority shareholders to reject tender offer if the redemption price is inappropriate. This conclusion is made on the basis of the article 15.3 of the Law on Security Market (LSM) according to which "all proposals or recommendations $[\ldots]$ on acceptance or repudiation of tender offer, as well as tender offer, must be conducted in accordance with regulations established by National Bank of Georgia." Since Entrepreneurs law of Georgia (EL) refers to LSM, the article 15.3 must be applied in case of mandatory tender offer (Burduli Irakli, 2007, 24).

Article 532 of EL regulates mandatory tender offers. One of the aspects of takeover is that buyer must offer fair price for the shares to minority shareholders.

Based on the article 532.2 of EL, the main principles of the redemption of shares could be highlighted:

- $\quad$ The price must be fair;

- The definition of fair price is not established by legislation;

- $\quad$ Price is evaluated by auditor or brokerage;

- The minimal price is established by EL which equals to the maximum price of the share for the past six months.

The problem with this regulation is that minority shareholders have no option to bargain and argue the established price. It is not comforting that EL establishes minimal price of redeeming shares, since this price equals to 
maximum price of the share for the past six months. Squeeze-outs are usually associated with a preceding low market flee-float, which affects the price of shares. Even though EL refers to "minimal price", in reality this is the only approach of the calculation of fair price that is offered by Georgian legislation or doctrine in contrast with the experience of European countries (Germany and Austria, for example) where several methodologies of evaluation are set in place and often applied simultaneously (Dollinger, 2008).

Next problem is that assessment is delegated to audits or brokerage firms, while brokerage is completely underdeveloped in Georgia. I am inclined to agree with the position offered in Georgian legal doctrine, which considers the possibility for the minority shareholders to address the court if they don't consent with offered tender price. Article 531.6 of EL must be applied in that case (legal analogy) (Burduli Irakli, 2007, 24-25). Also, it is still unclear what part the court system will play in the establishment fair price. Price of the share, itself, is not a legal category. Also, evaluation requires special knowledge which brings the necessity of expert conclusion. Some legal precision on the methods of evaluation is still necessary.

The institution of mandatory acquisition of shares is easily the most widely discussed institution in corporate law domain. From the very beginning, it was discussed and questioned whether this form of compulsory contracting was against freedom of property. Finally, it was agreed that since minority shareholders were offered fair prices, the restriction of their property was duly compensated and, therefore, valid.

The approach is much stricter in case of mandatory acquisition of shares. Article 534.2 of EL states that The court shall decide on a mandatory acquisition of shares as determined in the Civil Procedure Code of Georgia. The fair value and the date of share redemption would be fixed by the court decision on a mandatory acquisition of shares as determined in the Civil Procedure Code of Georgia (CPC).

It is important to keep in mind that first redaction of mandatory selling out of shares was declared void by Constitutional Court of Georgia. Basic argument was that the law did not ensure offering fair price to minority shareholders. Constitutional court supported the idea of evaluating shares by independent brokerage companies or experts. Nonetheless, it is still doubtful whether the procedure adopted after the decision of the Constitutional Court guarantees necessary protection to minority shareholders and assures them of due compensation for the restriction of their property.

Though EL declares boldly that court fixes fair price, the appropriate articles of CPC and practice gave a different impression.

Article $309^{12}(1-2)$ of CPC declares that to determine the fair redemption price of the shares, the court shall appoint an independent expert 
or a broker company within seven days after an application has been filed. An independent expert or a broker company shall prepare a redemption report that shall include documented circumstances of redemption as well as the method to be used for determining a fair redemption price of the shares and the price of the shares determined on that basis. The costs of an independent expert or a broker company shall be borne by the offeror.

The participation of parties is ensured only on the level of appointment of expert or brokerage. When selecting an independent expert or a broker company, the court may take into account the opinions of the parties. The parties may recommend to the court candidates to be appointed as experts. The final decision as to who is to prepare a redemption report shall be made by the court. The parties may challenge an independent expert or a broker company.

CPC does not grant the possibility of disputing offered price or representation of alternative evaluation to minority shareholders. In fact, court makes decision based on the evaluation provided under the Article $309^{12}$. Therefore, article $309^{14}$ CPC states that when establishing a fair price for redemption of shares, a court shall take into account:

a) the value of these shares on the stock market;

b) estimated revenues that the joint stock company may expect to gain in the future;

c) assets (including reserves, goodwill, experience, prospects and business relationships of the enterprise) and liabilities of the joint stock company.

CPC does not state based on which data court should enquire these measures. As already mentioned, those criteria are not legal and it requires special knowledge. Basically, court completely relies on the assessment of expert or broker.

Generally, no legal system establishes how fair price should be calculated, but several approaches are elaborated in case law. According to German practice, bottom value of redemption is the market value of the stock (Krebs, 2008, 961). Basically, same position was held by Delaware courts (Miliutis, 2013). Also, it is still a subject of discussion-should the valuation be based on the company value or on the value of the specific minority shares? Should the minority shareholders be benefitting from the transactions? In the theory, the opinion was raised that stocks should not be evaluated separately because the value of each stock could be different. This would infringe on the rule of equal treatment of all shareholders (Krebs, 2008, 964). Delaware case law stated that a fixed sum must be added to the evaluation of independent appraiser, considering the fact that the value of stock was reduced by the lack of controlling rights. This approach is widely criticized and believed to overcompensate minority shareholders (Miliutis, 2013, 786). 
Most common approaches of evaluation price of the stock are:

a. By market value; this means to compensate stocks according to market value of the stock in a given moment. This approach is not beneficial to minority shareholders as market value in a given moment of time might not reflect the real value of the shares. Naturally, Majority shareholders will choose the moment to buy out when the market price is the lowest (Miliutis, 2013, 780).

b. Third party sale value which means to establish the value of stock in accordance with the price payed in previous transactions. This approach is rejected by Delaware courts. The risk of this approach is that potential investor might be encouraged to reduce artificially the price of stocks (Miliutis, 2013, 782).

c. Going concern value. This method is one of the mostly accepted and it demonstrates that under appropriate management, the going concern value would have been equal or higher than the company's assets value.

d. The 'block approach' or 'multi-criterion approach' generally refers to the technique, which calculates the fair price of a squeeze-out by arithmetical or weighted average of different multiples, e.g. market price, value of company's assets, past earnings, etc. It is interesting to note that Delaware case law declares block approach as outdated (Miliutis, 2013, 784).

Georgian legislation is dubious somehow. CPC does not limit brokerage or expert and does not state which method must be applied to calculate fair price. However, article 309.14 is based on 'block approach'. CPC does not state based on which data should court enquire those indicators. There are several unanswered questions like if the expertise is carried out using different methodology, and how is the court supposed to get required information? Should the court itself request those materials from the company? General principles of Civil Procedure deprive courts this privilege and, also, has already mentioned these indicators as illegal and require special knowledge. The question is who must systemize the information for the court's use? What is the chance that dominating stakeholder will provide full information? Unfortunately, the answers are not offered by the case law either. Few decisions of Tbilisi city and Appeal Courts that are available on these matters, provided no groundings and only declared that the offered price is fair.

As for the Expert conclusion, generally, under CPC, all parties enjoy the possibility to challenge any proof provided by opponent party and represent alternative expert conclusion or evaluation. They are entitled to request additional or repeated expertise, while in the process of hearing cases on compulsory acquisition of shares, parties lack those options. The restriction of adversarial principle is inappropriate. Of course, the fact that those procedures are monitored by court is a much better regulation. Thus, 
the interests of parties are not sufficiently protected and by "parties" both the offeror and minority shareholders are meant, since broker might suggest risen or diminished redemption for shares.

The research shows that mandatory acquisition of shares requires several amendments. First of all, the 'take-over directive', from which Georgian legislator got an idea of squeeze-out, also includes alternative, equal right - mandatory sell-out of shares. It is the minority shareholders right to demand sell-out of shares and set themselves free from JSC. Georgian legislator left minority shareholders without this minimal protection.

It is quite important that case-law of Delaware state introduced business purpose tests when dealing with freeze-out mergers. In case of Singer v. Magnavox, the court stated that a merger could not be effected for the sole purpose of freezing-out minority shareholders (Krebs, 2008, 355).

The Constitutional Court of Georgia while dealing with 'freeze-out' stated that the desire of majority shareholder to own all the shares is only natural and understandable, but does not justify the restriction of property rights. Simply the fact that one of the shareholders holds $95 \%$ or more does not raise the social necessity of the acquisition of shares. The right of Mandatory acquisition of shares exists only when it is an absolute necessity for normal development and function of the company (Decision of the Constitutional Court of Georgia N2/1-370,382,390,402,405).

Therefore, the Constitutional Court supported the idea that mandatory acquisition or sell-out of shares (which is not nearly as strong restriction of property rights as squeeze-out) must be used only in those cases when justified. Unfortunately, the position of the Constitutional Court of Georgia was not taken into account when new redaction of squeeze-out was passed.

\section{Shareholders' Action}

Within the scope of protective rights, shareholders' lawsuit (action) is the most important right. The right to sue for the wrongful actions is a mechanism of protection of shareholder's interests when other rights are in peril of breach or already affected.

Shareholders' action is divided into two categories: direct lawsuit and derivative lawsuit. It is of vital importance to distinguish these two categories since not only do they serve different purposes and cause different results, but also the procedure and allocation of burden of proof are completely different.

The primary beneficiary of direct lawsuit is a shareholder himself, while the derivative lawsuit is brought on behalf of the company. Direct lawsuit is brought when shareholder considers that one of his rights was limited or he suffered damage by the breach of fiduciary duties or by abuse 
of power by the dominant shareholder. The burden of proof is divided between parties usually. The derivative lawsuit is brought when the company has a claim against third party, but is not using itself. If the claim is satisfied the company gets profit. The shareholder might only be an indirect beneficiary and also the other shareholders who haven't brought derivative lawsuit might equally benefit from the outcome of the court decision. In this sense, derivative lawsuit is a kind of action popularis. The mandatory prerequest is that company itself is not bringing charges against third party. Direct actions are not brought against third parties and respondents are other shareholders, directors, or dominant partner.

The Common law system gave birth to derivative lawsuit. In the UK, derivative lawsuits can be tracked down in some decisions from $19^{\text {th }}$ century $(16,2)$. In one of the earliest cases, Carlen $v$. Drury, the possibility of partner to bring suit instead of company was dismissed, but in following decade, gradually the action on behalf of the company was allowed.

Georgian court practice is not rich in this kind of actions. To be fair, derivative actions are not quite that a popular remedy elsewhere. Four main problems to blame are: a) the damage is not made directly to shareholder and the shareholder is not interested to act instead of company; b) positive outcome is highly questionable-It is quite difficult to prove that bringing charges against third party is in the best interest of the company while managerial bodies claim otherwise; c) Burden of proof lies on the plaintiff shareholder; d) derivative actions have bad impact on companies' reputation and make investors more reluctant to deal with those companies.

\section{Fiduciary Duties and Obligation to Compensate Damage}

When fiduciary duties are touched, most of the time, the directors and other managerial bodies are in mind and it is forgotten that shareholders also have equivalent fiduciary duties, especially dominant shareholder, the one who has possibility to influence the outcome of general meeting. The 'supreme' managerial body of JSC is a general meeting. Therefore, shareholders who have influence on the results of votes are subjects of fiduciary duties. It is debatable whether minority shareholders have fiduciary duties or not. For instance, German case-law states that minority shareholders have no such obligations.

To solve the question, it is important to keep in mind that dominant shareholder is not always a majority shareholder. In some situations, minority shareholders have power to influence decision-making processes. Therefore, they are also subjects of fiduciary duties. The statement is especially true in the case of so called 'dead-lock'. The article 8 and 115 of Civil Code of Georgia must also be used in such cases. The article 3.8 of EL 
states that dominant shareholder is obliged to pay due compensation to other shareholders in case of abuse of dominant position.

\section{Conclusion}

At the end, it is possible to determine several legal-practical amendments that will help in the process of protection of minority shareholders.

First of all, it is necessary that monitoring of redemption of shares was delegated to courts in the process of mandatory tender offers; for example, it is established by Austrian legislation.

The squeeze-out requires further legal amendments. First and foremost, the institution of mandatory sell-out of stocks must be implemented in Georgian legislation. Secondly, it is highly important to ensure that the recommendation of the Constitutional Court of Georgia is preserved and legislative frame for squeeze-out was set in place. Contrary to the statement of Constitutional Court of Georgia, amended institution of mandatory acquisition of shares does not set a prerequisite that acquisition or sell-out of shares might be initiated only for legitimate purposes and only in case when the necessity of squeeze-out is justified to preserve corporate interests or better protect minority shareholders' rights. Mandatory acquisition or sell-out of shares is justified only in those cases when it serves legal purposes and is a proportionate restriction of property rights in the light of necessity to better preserve corporate interests or ensure minority shareholders' interests.

It is inevitable to establish some approaches of evaluation of fair price at least by case law. The Approach of Delaware courts states that a fixed sum must be added to the evaluation of independent appraiser. Although this practice is criticized and believed to overcompensate minority shareholders, it is important to keep in mind that shareholders are not giving up the belongings that have fixed market value. However, they are deprived of the set of rights and obligations, the possibility of receiving stable income included, that come as a package with the possession of shares. Furthermore, the moral aspects of the transactions must be noted: the weaker party of the obligation is unwillingly giving up the property to meet the interests of other private person. Also, slight unbalance in favor of minority shareholders is admissible and appropriate.

The chapter of CPC dealing with mandatory acquisition of shares must be amended and must not restrict such elements of adversarial principle as possibility to provide proofs, to request alternative, repeated or additional expertise.

Currently, it is not advisable to delegate evaluation to broker companies as brokerage is not properly evaluated in Georgia. 
Georgian legislation acknowledges only two classes of stocks. The international market knows several classes of shares. The emission of different shares is a good way to control participation in decision-making process. The several forms of preferred shares allow investors interests to move into dividends without transmission of managerial rights. It is important to encourage usage of this measure by appropriate legal amendments.

Georgian legislation does not include shareholders agreement as a best way to protect minority and majority shareholders interests and provide solution for every possible conflict of interests.

Finally, it is very important to adopt the principle of mandatory participation of minority shareholders into controlling bodies of JSC. In the case of Georgia, the representatives of minority shareholders should be nominated into the board of supervisors.

\section{References:}

1. Bainbridge, S.M. (2002). Corporation Law and Economics, New York (Foundation Press).

2. Boyle, A.J. (2002). Minority Shareholder's Remedies, Cambridge, Cambridge Studies in Corporate Law.

3. Burduli Irakli (2013). Essentials of JSC Law, vol. 2, Tbilisi.

4. Burduli Irakli (2007). Mandatory Tender Offer, Mandatory Acquisition of Shares, Improper Use of Power Granted by Share or Necessary Measure for Development Security Market? Justice, N2, 2007, 10-39;

5. Case of Kahn v. Lynch, 638 A.2d 1110 (Del. 1994), http://www.invispress.com/law/corporations/lynch.html;

6. Case of Weinberger v. UOP, Inc. 457 A.2d 701 (1983), http://law.justia.com/cases/delaware/supreme-court/1983/457-a-2d701-4.html

7. Code of Civil Procedure of Georgia, Register of The Parliament of Georgia (2017) 47-48, 07, 31/12/1997, www.matsne.gov.ge.

8. Decision of the Constitutional Court of Georgia N2/1370,382,390,402,405; www.constcourt.ge

9. Decision of Tbilisi Appeal Court N1749-10.

10. Decision of Tbilisi Appeal Court N1115-09

11. Decision of Tbilisi City Court N2/88-10

12. Decision of the Supreme Court of Georgia Nas-1343-1361-2011

13. Dollinger, M. (2008). The Fair Squeeze-out Compensation, https://books.google.ge/books?id=QSp7dekYvpAC\&dq=fair+price + p rinciple+squeeze+out\&source=gbs_navlinks_s; 
14. Entrepreneurs Law of Georgia, Register of The Parliament of Georgia (2017). 21-22, 07 www.matsne.gov.ge.

15. Khurtsilava Robinzon (2009). Simplified Hearing in Civil Procedure of Georgia, Meridiani Publishing.

16. Krebs, C.A. (2008). Freeze-Out Transactions in Germany and the U.S.: A Comparative Analysis, German Law Journal, 2008, vol.13, 941-978.

17. Law on Security Market, Legislative Herald of Georgia (2017). 1(8), 14/01/1999, www.matsne.gov.ge.

18. Miliutis, F. (2013). Fair Price in Squeeze-out Transactions, Societal Studies, Mykolas Romeris University Publishing, 5 (3) 769-792.

19. Poisson, M. D. (1994). La Protection des Actionnaires Minoritaires Dans Les Sociétés De Capitaux. These Présenté et publiquement sutenue devant la Faculté de Droit et de Science Politique de l'Université de Clermont.

20. Thamm, C. (2013). Minority Shareholder Monitoring and German Corporate Governance: Empirical Evidence and Value Effects Corporate Finance and Governance, Academic Research.

21. Tsertsvadze Lasha (2016). Directorate Obligations on Merging of Companies and Acquiring Control Packet, Lawyer's World. 